Research article

\title{
Synthesis and Characterization of Biodiesel from Tofu Dregs Oil through Esterification and Transesterification Irradiated by Microwave
}

\author{
Niyar Candra Agustin ${ }^{*}$, Ricka Prasdiantika', Yustika Kusumawardani ${ }^{1}$ \\ 'Engineering Faculty, Universitas Pandanaran, Jl. Banjarsari Barat No. o1, Pedalangan, Banyumanik, \\ Semarang, Indonesia 50268 \\ * Corresponding author, e-mail: niyaragustin@gmail.com
}

\begin{abstract}
Biodiesel has become an alternative energy source that continues to be developed. In this research, biodiesel synthesis from tofu dregs oil has been carried out through two stages of the reaction, namely the esterification stage using $\mathrm{H}_{2} \mathrm{SO}_{4}$ catalyst to reduce the content of FFA (Free Fatty Acid) and the transesterification stage using $\mathrm{KOH}$ catalyst to produce biodiesel. The esterification reaction using $2 \%$ $\mathrm{H}_{2} \mathrm{SO}_{4}$ catalyst was carried out by microwave heating at power variation of the microwave power 150, 300, 450, 6oo, 800 watt with a reaction time of 10 minutes. The transesterification reaction was carried out with variations in microwave power of 150, 300, 450, 600, 800 watts and variations of the reaction time of 5, 10 ,15, 20, and 25 minutes. Biodiesel products were characterized using Gas Chromatography-Mass Spectroscopy (GC-MS), Hydrogen-1 Nuclear Magnetic Resonance (1H-NMR) spectrometer, and feasibility test with the American Standard for Testing Material (ASTM). The characterization results showed that tofu dregs oil biodiesel has been successfully synthesized. The optimum biodiesel was achieved at 6oo Watt microwave power with a reaction time of 20 minutes at $92 \%$. The formation of biodiesel is evidenced by several methyl ester peaks, namely methyl oleate (59.98\%), methyl linolenic (28.13\%), methyl palmitate (8.54\%), and methyl stearate (2.32\%). Based on the results of ASTM biodiesel tofu dregs oil has met SNI-04$7182-2006$ standards, namely the specific density parameter $60 / 60^{\circ} \mathrm{F}\left(0.87 \mathrm{~g} / \mathrm{cm}^{3}\right)$, kinematic viscosity at $40^{\circ} \mathrm{C}\left(4.3 \mathrm{~mm}^{2} / \mathrm{s}\right)$, pour point $\left(8^{\circ} \mathrm{C}\right)$, flash point $\left(202{ }^{\circ} \mathrm{C}\right)$ and cloud point $(7)^{\circ} \mathrm{C}$ for biodiesel.
\end{abstract}

Keywords: synthesis, biodiesel, tofu dregs, microwave

\section{Introduction}

The advantages of biodiesel as a source of energy are that it is an energy source that can increase, low gas emissions, and is sustainable energy (Lin et al., 2014). Biodiesel can be synthesized from oil (triglycerides) which is reacted with alcohol with the help of a catalyst (Chen et al., 2012). Sources of oil that can be used as raw material for biodiesel can come from animal oil or vegetable oil (Srilatha et al., 2012). Corn oil, palm oil, sunflower seed oil, coconut oil, and soybean oil are oils that have been studied as raw materials for biodiesel (Lin et al., 2014). The use of these oils as raw materials in making biodiesel can cause competition problems with other human needs, namely food. Efforts to overcome this problem are by utilizing the oil contained in tofu dregs as an alternative source of oil in making biodiesel (Buchori et al., 2012).

Tofu dregs oil can be used as a source of oil in making biodiesel but contains free fatty acids. The content of FFA in tofu dregs oil makes tofu dregs oil not optimally converted into methyl ester or biodiesel by transesterification using an alkaline catalyst. The FFA content in oil can cause interference with the transesterification reaction, namely the formation of soap. The formation of soap in the oil transesterification reaction can cause the biodiesel produced to be not optimal and the separation of 
methyl ester from glycerol is difficult. (Nurfitri et al., 2013). One way to overcome this problem is to carry out the esterification stage of tofu dregs oil which aims to reduce the FFA content.

The esterification reaction is the reaction between carboxylic acids and alcohols to form an ester compound with a water byproduct (Nurfitri et al., 2013). FFA esterification in oil aims to convert the FFA contained in oil into ester compounds so that the FFA content in the oil can be reduced. In the esterification reaction, a homogeneous acid catalyst is used in the form of strong acids such as $\mathrm{H}_{2} \mathrm{SO}_{4}$, ptoluene sulfonic acid, and HF (Kuwahara et al., 2014) and in the transesterification reaction a catalyst is used, namely a homogeneous base catalyst such as $\mathrm{NaOH}, \mathrm{KOH}$ or methoxide, the use of acid and base catalysts because of their high activity (Qiu et al., 2011). The synthesis of biodiesel from tofu dregs has been carried out in two stages, namely esterification with a $\mathrm{H}_{2} \mathrm{SO}_{4}$ catalyst followed by transesterification with a homogeneous $\mathrm{NaOH}$ catalyst using conventional heating for 90 minutes with a biodiesel yield of 61.69\% (Anggraini et al., 2018). Conventional heating takes a long time so that the synthesis of biodiesel from tofu dregs oil is less efficient. Therefore, in this study, the synthesis of tofu dregs biodiesel was carried out by another heating method, namely the microwave heating method to obtain the optimum tofu dregs biodiesel with a faster reaction time.

Microwave heating takes place simultaneously whereas with conventional heating the heat flows by convection or conduction (Sajjadi et al., 2014). In the manufacture of biodiesel, microwave heating energy consumption is 10 times less than conventional heating (Lin et al., 2014; Patil et al., 2010). Another advantage of the microwave is that it only requires less energy input compared to conventional heating, is safer, heating time is faster, and is more environmentally friendly (Agustin and Prasdiantika, 2020). The factors that influence the manufacture of biodiesel by microwave heating are the ratio of reactants, reaction speed, reaction time, and microwave power (Purwaningrum and Sukaryo, 2020). The increase in reaction speed is the main advantage of using the microwave as a heating method in a reaction so that the reaction time is shorter (Gude et al., 2012). The amount of microwave power can affect the results of the esterification reaction to reduce FFA levels in oil and the transesterification reaction in making biodiesel (Purwaningrum and Sukaryo, 2020). So that the microwave power and the optimum reaction time must be determined to produce the optimum biodiesel. Therefore, in this study, biodiesel was synthesized from tofu dregs oil by microwave heating and determined the optimum microwave power in the esterification reaction to obtain tofu dregs oil with the lowest FFA content, as well as determining the optimum microwave power and reaction time in the transesterification reaction to obtain the optimum amount of tofu dregs oil biodiesel.

\section{Method}

The stages of this research consisted of extracting oil from tofu dregs, synthesizing biodiesel from tofu dregs oil in two stages, namely the esterification reaction using an $\mathrm{H}_{2} \mathrm{SO}_{4}$ catalyst to reduce FFA levels in tofu dregs oil and the transesterification reaction using a $\mathrm{KOH}$ catalyst to convert triglycerides from tofu dregs oil into biodiesel. In the esterification and transesterification reaction stages using microwave heating techniques and characterization of the resulting biodiesel.

\subsection{Materials}

The equipment used consisted of a shock extractor, a separating funnel, a microwave heating set (Microwave, Samsung ME83M Solo). The equipment used for the analysis of the resulting biodiesel is Gas Chromatography-Mass Spectroscopy (GC-MS, Shimadzu QP2010S) to determine the ester compounds contained in biodiesel and Hydrogen-1 Nuclear Magnetic Resonance (1H-NMR, JEOL ECP40o) for conversion analysis of triglycerides to biodiesel. American Standard for Testing Materials (ASTM) standard test equipment for testing the physical properties of biodiesel. The materials used consisted of tofu dregs and other materials with pro analysis qualities, namely n-hexane (Merck, 99.0\%), methanol (Merck, 99.8\%), $\mathrm{H}_{2} \mathrm{SO}_{4}$ (Merck, 95-97\%), $\mathrm{KOH}$ (Merck. ), $\mathrm{NaOH}$ (Merck), $\mathrm{Na}_{2} \mathrm{SO}_{4}$ anhydrous (Merck), and the phenolphthalein indicator (Merck). 
A total of 100 grams of tofu dregs were extracted using shock extraction using n-hexane solvent for 4 hours followed by evaporation to remove the remaining solvent. The tofu dregs oil that has been extracted from the tofu dregs is then analyzed for its FFA content.

\subsection{Esterification of Tofu Dregs Oil}

The esterification reaction was carried out by mixing 10 grams of tofu dregs oil and added with methanol. The mole ratio of oil to methanol is 1:15. The catalyst used in the esterification reaction of tofu dregs oil is the $\mathrm{H}_{2} \mathrm{SO}_{4}$ catalyst to reduce the FFA level in tofu dregs oil by $2 \%$ of the total weight of tofu dregs oil and methanol (Anggraini et al., 2018). The esterification reaction used a variation of microwave power at 150, 300, 450, 600, and 800 watts with a reaction time of 10 minutes. The esterified oil was analyzed for FFA content.

\subsection{FFA Content Justification}

A total of $20 \mathrm{~mL}$ of methanol was added to 2 grams of oil then heated to $45^{\circ} \mathrm{C}$ then titrated with o.1 $\mathrm{M} \mathrm{NaOH}$ with the addition of the phenolphthalein indicator. FFA levels are determined using the following equation:

$$
\% \text { FFA }=\frac{m L \mathrm{NaOH} \times \mathrm{N} \mathrm{NaOH} \times \text { fatty acid moleculer weight }}{\text { sample weight } \times 1000} \times 100 \%
$$

\subsection{Transesterification of Esterified Oil}

The transesterification reaction aims to obtain biodiesel from tofu dregs oil. The transesterification reaction was carried out by mixing 10 grams of esterified oil with methanol with a ratio of oil to methanol, namely 1:12. The $\mathrm{KOH}$ catalyst used in the transesterification reaction was $5 \%$ of the total weight of oil and methanol. The transesterification reaction with the microwave was carried out with power variations, namely $150,300,450,600$, and 800 watts and the variation of reaction time, namely $5,10,15,20$, and 25 minutes. Separation of biodiesel from glycerol using a separating funnel. The resulting biodiesel was washed with hot distilled water to dissolve the remaining glycerol and added anhydrous $\mathrm{Na}_{2} \mathrm{SO}_{4}$ to remove the remaining water then analyzed by GC-MS, $1 \mathrm{H}-\mathrm{NMR}$ spectrometer.

\subsection{Biodiesel feasibility test using the ASTM method}

The biodiesel feasibility test is analyzed based on the American Standard for Testing Materials (ASTM) method which has been standardized by the National Standardization Agency with quality requirements according to SNI-04-7182-2006.

\section{Result and Discussion}

\subsection{Esterification of Tofu Dregs Oil by Microwave Heating}

Tofu dregs oil extracted from tofu dregs contains $4.6 \%$ FFA. FFA levels in oil more than $2.5 \%$ can interfere with the transesterification reaction (Nurfitri et al., 2013). Therefore, this research requires an esterification reaction step against tofu dregs oil. The esterification reaction of tofu dregs oil was carried out by varying the microwave power of 150, 300, 450,600, and 800 watts with a reaction time of 10 minutes to determine the microwave power with the highest reduction in FFA content. Table 1 shows the relationship between microwave power and the FFA content of tofu dregs oil.

Table 1. FFA content of tofu dregs oil with various microwave irradiation power

\begin{tabular}{cc}
\hline Microwave Irradiation Power (watt) & FFA (\%) \\
\hline $\mathbf{1 5 0}$ & 4.4 \\
$\mathbf{3 0 0}$ & 3 \\
$\mathbf{4 5 0}$ & 1.4 \\
\hline
\end{tabular}




\begin{tabular}{cc}
\hline Microwave Irradiation Power (watt) & FFA (\%) \\
\hline $\mathbf{6 0 0}$ & 1.8 \\
$\mathbf{8 0 0}$ & 2.6 \\
\hline
\end{tabular}

The initial FFA content in tofu dregs oil in this study was $4.6 \%$. Based on Table 1 , it can be seen that the esterification stage using a microwave catalyst $\mathrm{H}_{2} \mathrm{SO}_{4}$ has succeeded in reducing the FFA content in tofu dregs oil. The decrease in FFA increases with the increase in microwave power used. There was a decrease in the highest FFA content at 450 watts of microwave power with the FFA content in tofu dregs oil of $1.4 \%$. At 600 and 800 watts of microwave power, the FFA levels in tofu dregs oil were higher than those in 450 watts of microwave power. This is because organic molecules such as triglycerides can be broken down into FFA by too high a microwave power (Saifuddin and Chua, 2004). This study has succeeded in reducing the FFA content of tofu dregs oil from $4.6 \%$ to $1.4 \%$.

\subsection{Transesterification of Esterified Oil by Microwave Heating}

Microwave heating occurs when the electric field of radiation interacts with polar compounds, which can cause molecular motion such as dipole rotation or ion migration (Sajjadi et al., 2014). The transesterification reaction with microwave radiation is related to the direct adsorption of microwave radiation by polar groups $(\mathrm{OH})$ from the reactants (Lertsathapornsuk et al., 2008). Methanol is an excellent material for absorbing microwave radiation because the methanol dipole is reoriented, which can damage the interface layer between methanol and oil, thereby increasing the reaction between alcohol and oil. Therefore, microwave radiation increases the solubility of methanol and oil and increases the speed of the transesterification reaction (Lidstrom et al., 2016). The transesterification reaction in this study was carried out on esterified tofu dregs oil with variations in microwave power, namely 150 , 300, 450,600 , and 800 watts with variations in reaction time for $5,10,15,20$, and 25 minutes with KOH catalyst for knowing the maximum power and time in increasing biodiesel products.

\subsubsection{Effect of Microwave Power}

Table 2. Biodiesel from tofu dregs oil with various microwave irradiation power

\begin{tabular}{cc}
\hline $\begin{array}{c}\text { Microwave Irradiation Power } \\
\text { (watt) }\end{array}$ & Biodiesel (\%) \\
\hline 150 & 40 \\
300 & 56 \\
450 & 76 \\
600 & 81 \\
800 & 78 \\
\hline
\end{tabular}

Table 2. shows the relationship between microwave power and the yield of biodiesel products. The yield of biodiesel conversion increases with increasing microwave power used. The optimum microwave power is at 600 Watt with the amount of biodiesel produced by $81 \%$. At 800 watts microwave power, tofu dregs oil biodiesel is lower than at 600 watts microwave power. This can be caused by an increase in the excess reaction temperature which will cause the evaporation of methanol so that it reduces the methanol content in the reactants, this decrease will cause a reduction in the conversion reaction between triglycerides and methanol so that the number of methyl esters produced will be reduced. This can also be due to the increase in microwave power, the temperature and reaction speed increase, but the back reaction speed increases so that the biodiesel produced is not as much as at 600 watts of power. (Hong et al., 2016). 
<smiles>[R]C(=O)OCCCOCCC(=O)OC(COC([R])=O)COC([R])=O</smiles>

Triglyceride Methoxide ion<smiles>[R]C(=O)OCC(CO)OC(=O)N=CC(=O)OC(C[O-])COC([R])(C)[O-]</smiles><smiles>[R]C(=O)OCC(C[O-])OC([R])=O</smiles>

Figure 2. The transesterification mechanism of tofu dregs oil with base catalyst (Fitriyana et al., 2012)

\subsubsection{Effect of Reaction Time}

After obtaining the optimum microwave power, it was carried out by varying the reaction time of $5,10,15,20$, and 25 minutes at 600 watts of microwave power to determine the optimum reaction time that was able to produce the highest biodiesel. Table 3 shows that the highest amount of biodiesel was obtained with a reaction time of 20 minutes, which was $92 \%$. The amount of tofu dregs oil biodiesel obtained with a reaction time of 5 minutes was still small, namely $64 \%$. This is because the oil has not fully reacted with methanol (Hong et al., 2016). The increasing the reaction time, the greater the microwave radiation emitted. The greater the microwave radiation emitted to the oil and methanol, the greater the radiation absorbed by these compounds. The electromagnetic field from microwave radiation causes the reorientation of oil and methanol compounds. The greater the reorientation of the oil and methanol compounds, the greater the conversion of kinetic energy into heat energy so that the random motion of the molecules increases. The more random motion of oil and methanol molecules causes more transesterification reactions between oil and methanol to produce biodiesel.

Table 3. Biodiesel from tofu dregs oil with various reaction times

\begin{tabular}{cc}
\hline Reaction time (minute) & Biodiesel (\%) \\
\hline $\mathbf{5}$ & 65 \\
$\mathbf{1 0}$ & 81 \\
$\mathbf{1 5}$ & 85 \\
$\mathbf{2 0}$ & 92 \\
$\mathbf{2 5}$ & 87 \\
\hline
\end{tabular}

\section{$3 \cdot 3$}

\section{Biodiesel Characterization}

The resulting biodiesel was characterized using GC-MS and $1 \mathrm{H}-\mathrm{NMR}$ spectrometer and the biodiesel feasibility test was carried out using the ASTM method to determine the physical properties of tofu dregs oil biodiesel.

\subsubsection{Results of GC-MS biodiesel analysis}

GC-MS analysis of biodiesel aims to determine the components of the compounds contained in biodiesel. Figure 2.is a chromatogram of the results of the analysis of tofu dregs oil biodiesel from the analysis using GC. The figure shows that there are several peaks detected as methyl esters. The compound content of tofu dregs oil biodiesel is shown in Table 4. 


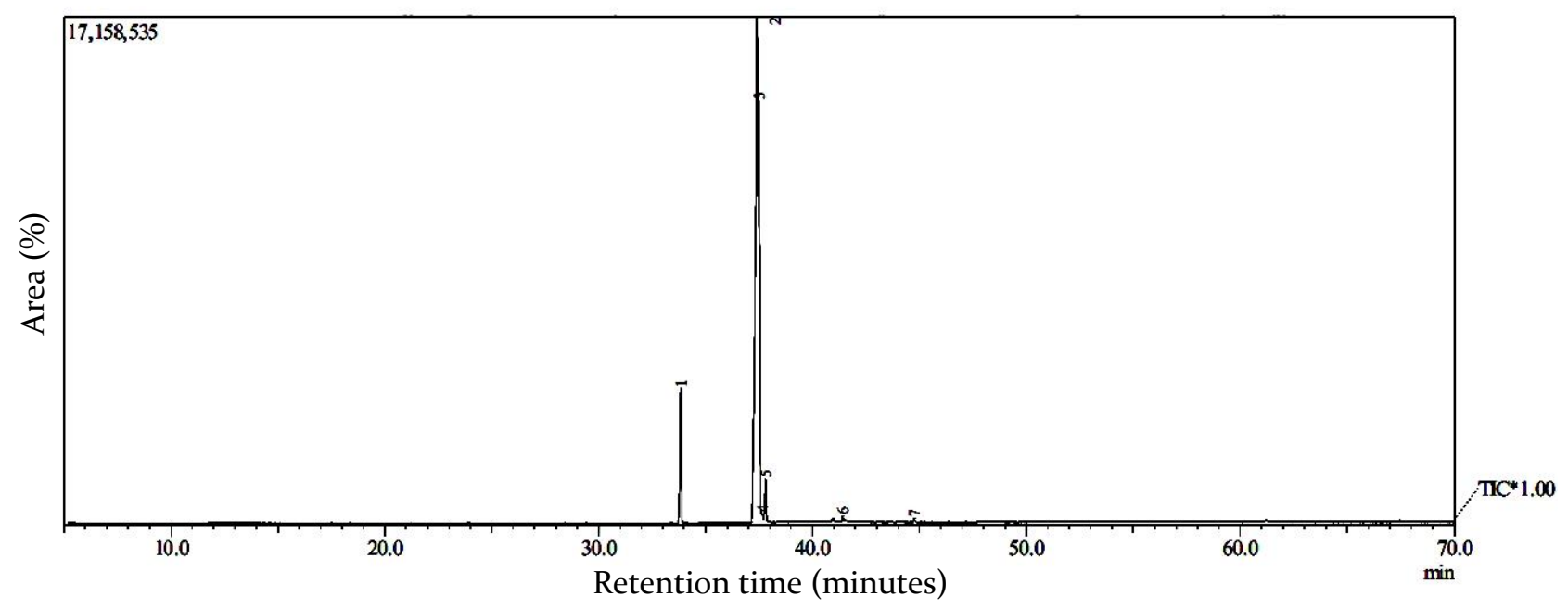

Figure 2. Chromatogram of biodiesel from tofu dregs oil

The peaks from the GC analysis were then analyzed by MS and the resulting mass spectral patterns were compared with the database. The results show that the main content of biodiesel that has been synthesized in this study is methyl ester (biodiesel) as shown in Table 4. The area stated (\%) in the characterization results by GC-MS shows the levels of methyl ester compounds contained in biodiesel from tofu dregs.

Table 4. Methyl ester of biodiesel from tofu dregs oil

\begin{tabular}{ccl}
\hline Peak & Methyl ester & Area (\%) \\
\hline 1 & Methyl palmitate & 8,54 \\
2 & Methyl oleate & 59,98 \\
3 & Methyl linolenic & $\mathbf{2 8 , 1 3}$ \\
4 & Methyl sterate & 2,32 \\
\hline
\end{tabular}

\subsubsection{Results of $1 \mathrm{H}-\mathrm{NMR}$ spectrometer analysis}

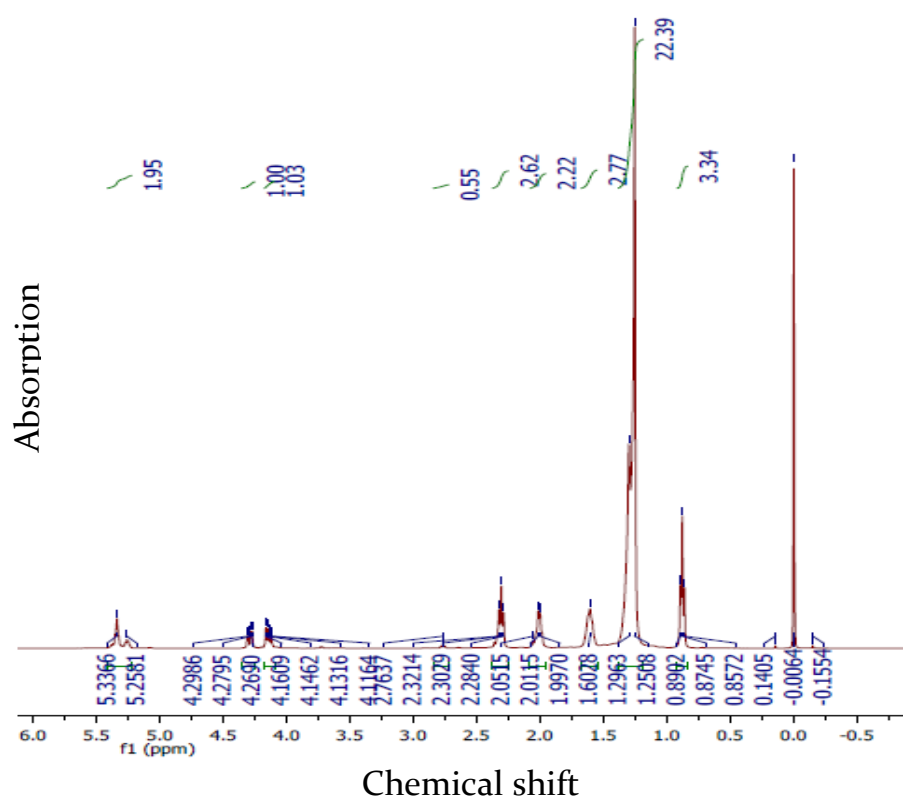

Figure 3. ${ }^{1} \mathrm{H}-\mathrm{NMR}$ spectra of tofu dregs oil 
Tofu dregs oil that has been successfully extracted is analyzed with a $1 \mathrm{H}-\mathrm{NMR}$ spectrometer shown in Figure 3. Figure 3 shows that the $1 \mathrm{H}-\mathrm{NMR}$ spectra of tofu dregs oil have a peak with an integration value of 2.03 at a chemical shift of about 4.1-4, 4 ppm which is the typical peak $-\mathrm{CH}_{2}-\mathrm{O}$ - of triglycerides (Ouanji et al., 2016). These results indicate that this research has succeeded in extracting oil from tofu dregs.

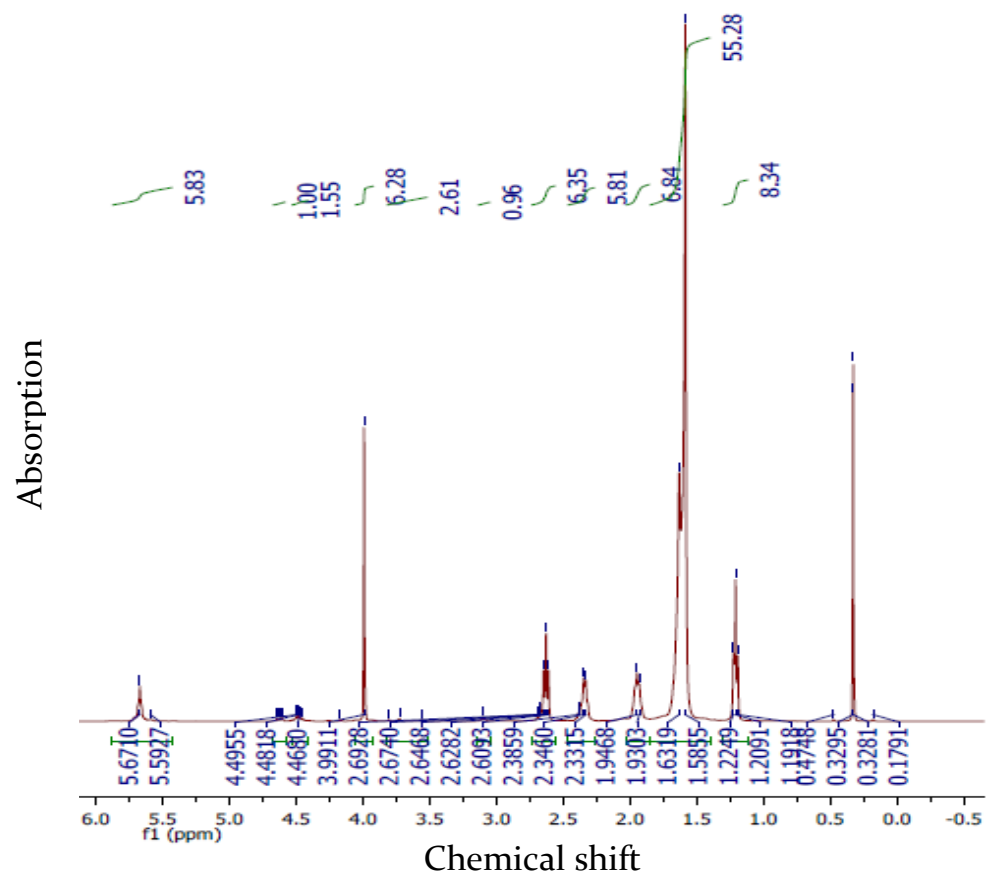

Figure 4. ${ }^{1} \mathrm{H}-\mathrm{NMR}$ spectra of biodiesel from tofu dregs oil

Figure 4. shows the $1 \mathrm{H}-\mathrm{NMR}$ spectra of tofu dregs oil biodiesel, there is a very low triglyceride peak in the 4.1-4.4 ppm area which indicates that there are still triglycerides in tofu dregs oil biodiesel that have not been completely converted into methyl esters. A typical peak of biodiesel appears at a chemical shift of $3.99 \mathrm{ppm}$ with an integration value of 6.28. The spectra did not show the presence of a typical glycerol peak at the 5,2 chemical shift. This shows that the separation between glycerol and biodiesel washing has succeeded in separating biodiesel and glycerol as a byproduct of the transesterification reaction. Based on the $1 \mathrm{H}-\mathrm{NMR}$ spectra of tofu dregs oil with $1 \mathrm{H}-\mathrm{NMR}$ spectra of tofu dregs oil biodiesel, it is proven that the triglycerides contained in tofu dregs oil have been converted into biodiesel.

\subsubsection{The results of the biodiesel feasibility test}

Table 5. Comparison of properties of biodiesel from tofu dregs oil and biodiesel standards in Indonesia (SNI-04-7182-2006)

\begin{tabular}{llc}
\hline \multicolumn{1}{c}{ Parameter } & Biodiesel & Biodiesel from tofu dregs oil \\
\hline Specific density $60 / 60{ }^{\circ} \mathrm{F}, \mathrm{gr} / \mathrm{cm}^{3}$ & $0,85-\mathrm{o}, 92$ & 0.87 \\
Kinematic viscosity at $4 \mathrm{o}^{\circ} \mathrm{C}, \mathrm{mm}^{2} / \mathrm{s}$ & $2,3-6, \mathrm{o}$ & 4,3 \\
Pour point, ${ }^{\circ} \mathrm{C}$ & Max. 18 & 8 \\
Flash point, ${ }^{\circ} \mathrm{C}$ & Min. 100 & 202 \\
Cloud point, ${ }^{\circ} \mathrm{C}$ & Max. 18 & 7 \\
Conradson carbon residue $(\% \mathrm{w} / \mathrm{w})$ & Max o,o5 & $\mathrm{o}, 13$ \\
Water content, $\%$ vol & Max. o,o5 & $\mathrm{o}, 8$ \\
\hline
\end{tabular}

The biodiesel feasibility test is carried out by comparing the biodiesel obtained with the biodiesel feasibility standard based on SNI-04-7182-2006 using several parameters, namely specific density (6o/6o $\left.{ }^{\circ} \mathrm{F}, \mathrm{g} / \mathrm{cm}^{3}\right)$, kinematic viscosity $\left(40^{\circ} \mathrm{C}, \mathrm{mm}^{2} / \mathrm{s}\right)$, flash point, pour point, fog point, residual carbon, and 
water content. Table 5 . shows the comparison of the values of the seven parameters between standard SNI-04-7182-2006 diesel oil and the test results on tofu dregs oil biodiesel. Table 5 shows that the esterification process followed by transesterification has changed the physical properties of tofu dregs oil. Based on Table 5 it can be seen that the physical properties of tofu dregs oil biodiesel are in the range of the SNI-04-7182-2006 parameter specifications, namely the specific density $\left(60 / 60^{\circ} \mathrm{F}\right)$ of tofu dregs oil biodiesel of $0.87 \mathrm{gr} / \mathrm{cm}^{3}$, kinematic viscosity at $40^{\circ} \mathrm{C}$ of $4.3 \mathrm{~mm}^{2} / \mathrm{s}$, pour point of $8{ }^{\circ} \mathrm{C}$, the flashpoint of $202{ }^{\circ} \mathrm{C}$, and fog point of $7^{\circ} \mathrm{C}$ so that it can be said that tofu dregs biodiesel meets biodiesel standards (Purwaningrum and Sukaryo, 2020).

Conradson carbon residue from tofu dregs oil biodiesel exceeds the SNI standard limit for biodiesel which is $0.24 \% \mathrm{~b}$. This is because there are still triglycerides that have not been converted into methyl esters, causing incomplete combustion and producing carbon residue. This analysis is supported by the results of the $1 \mathrm{H}-\mathrm{NMR}$ spectra analysis of tofu dregs oil biodiesel that there is a very low triglyceride peak in the 4.1-4.4 ppm area which indicates that there are still triglycerides in tofu dregs oil biodiesel. The water content in tofu dregs oil biodiesel still exceeds the SNI standard, which is $0.8 \%$ vol. The high water content in biodiesel in tofu dregs oil can be caused when washing biodiesel with warm water to dissolve the remaining glycerol, there is still water left in the biodiesel. The high water content in biodiesel can cause the heat energy produced in the biodiesel combustion process to decrease.

\section{Conclusion}

The characterization results show that tofu dregs oil biodiesel has been successfully synthesized. The esterification reaction at 450 watts with a reaction time of 10 minutes has succeeded in reducing the FFA content of tofu dregs oil from $4.6 \%$ to $1.4 \%$. The optimum biodiesel is achieved at 600 watts of power with a reaction time of 20 minutes at $92 \%$. The formation of biodiesel is evidenced by several methyl ester peaks, namely methyl oleate (59.98\%), methyl linolenic acid (28.13\%), methyl palmitate (8.54\%), and methyl stearate (2.32\%). Based on the results of ASTM tofu dregs oil biodiesel has met SNI-04-7182-2006 standards, namely the specific density parameter $60 / 60^{\circ} \mathrm{F}\left(0.87 \mathrm{~g} / \mathrm{cm}^{3}\right)$, kinematic viscosity at $40^{\circ} \mathrm{C}(4.3$ $\left.\mathrm{mm}^{2} / \mathrm{s}\right)$, pour point $\left(8^{\circ} \mathrm{C}\right)$, flash point $\left(202^{\circ} \mathrm{C}\right)$ and fog point $\left(7^{\circ} \mathrm{C}\right)$ for biodiesel.

\section{Acknowledgment}

Thank you to the Directorate of Research and Community Service of the Ministry of Research, Technology and Higher Education for funding this research with the Beginner Lecturer Research grant scheme for the 2020 fiscal year with Research contract number 017/L6/AK/SP2H/Research/2020 between the Regional Higher Education Service Institutions (LLDIKTI) VI Central Java with LPPM Pandanaran University and Head of Research so that this research can be carried out well.

\section{Reference}

Agustin, N.C. and Prasdiantika, R. 2020. Sintesis Natrium Zirkonia Sebagai Katalis Reaksi Transesterifikasi Minyak Goreng Bekas. Jurnal Presipitasi 17 (1), 44-51.

Anggraini, T.M. and Fitriani, N. 2018. Limbah Ampas Tahu Sebagai Bahan Baku Untuk Produksi Biodiesel, Jurnal Integrasi Proses 7 (1), 13-19.

Buchori, L., Sasongko, S.B., Anggoro, D.D., and Aryanti, N. 2012. Pengambilan Minyak Kedelai Dari Ampas Tahu Sebagai Bahan Baku Pembuatan Biodiesel. Jurnal Ilmu Lingkungan 1o(2), 49-53.

Chen, K. S., Lin, Y. C., Hsu, K. H., and Wang, H. K. 2012. Improving Biodiesel Yields From Waste Cooking Oil By Using Sodium Methoxide And A Microwave Heating System. Energy 38(1), 151-156.

Fitriyana, L. A., Soeprodjo, S., Kadarwati, S. 2012. Produksi Biodiesel Dari Dedak Padi (Rice Bran) Melalui Dua Tahap Reaksi In-Situ. Indonesian Journal of Chemical Science 2, 140-146.

Gude, V. G., Patil, P., Martinez-guerra, Deng, S., and Nirmalakhandan, N. 2013. Microwave energy potential for biodiesel production. Sustainable Chemical Processes 1 (5), 1-31.

Hong, I.K., Jeon, H., Kim, H., and Yamashita, H. 2016. Preparation Of Waste Cooking Oil Based Biodiesel 
Using Microwave Irradiation Energy. Journal of Industrial and Engineering Chemistry 42, 107-112.

Kuwahara, Y., Fujitani, T., and Yamashita, H. 2014. Esterification Of Levulinic Acid With Ethanol Over Sulfated Mesoporous Zirconosilicates : Influences Of The Preparation Conditions On The Structural Properties And Catalytic Performances. Catalysis Today, 237, 18-28.

Lertsathapornsuk, V., Pairintra, R., Aryusuk, K., and Krisnangkura, K. 2008. Microwave Assisted In Continuous Biodiesel Production From Waste Frying Palm Oil And Its Performance In A $100 \mathrm{Kw}$ Diesel Generator. Fuel Processing Technology, 89(12), 1330-1336.

Lidstrom, P., Tierney, J., Wathey, B., and Westman, J. 2001. Microwave Assisted Organic Synthesis. Tetrahedron 57 (589), 9225-9283.

Lin, Y., Chen, S., Chen, C., Yang, P., and Jhang, S. 2014. Rapid Jatropha-Biodiesel Production Assisted By A Microwave System And A Sodium Amide Catalyst. FUEL, 135, 435-442.

Nurfitri, I., Maniam, G.P., Hindryawati, N., Yusoff, M. M., and Ganesan, S. 2013. Potential of feedstock and Catalysts From Waste In Biodiesel Preparation: A review. Energy Conversion and Management, 74, 395-402.

Ouanji, F., Nachid, M., Kacimi, M., Liotta, L. F., Puleo, F., and Ziyad, M. 2016. Small Scale Biodiesel Synthesis From Waste Frying Oil And Crude Methanol In Morocco. Chinese Journal of Chemical Engineering, 24(9), 1178-1185.

Patil, P. D., Gude, V. G., Camacho, L. M., and Deng, S. 2010. Microwave-assisted catalytic transesterification of camelina sativa oil. Energy and Fuels, 24(2), 1298-1304.

Purwaningrum, S. D., and Sukaryo. 2020. Pengolahan Limbah Ikan Menjadi Biodiesel dengan Radiasi. Jurnal Presipitasi 17(1), 38-43.

Qiu, F., Li, Y., Yang, D., Li, X., and Sun, P. 2011. Heterogeneous solid base nanocatalyst: Preparation, characterization and application in biodiesel production. Bioresource Technology, 102(5), 41504156.

Saifudin, N., and Chua, K.H. 2004. Production Ethyl Ester (biodiesel) from Used Frying Oil: Optimization of Transesterification Prosess using Microwave Irradiation. Malaysia Journal of Chemical 6, 077-82.

Sajjadi, B., Aziz, A. R. A., and Ibrahim, S. 2014. Investigation, modelling and reviewing the effective parameters in microwave-assisted transesteri fi cation. Renewable and Sustainable Energy Reviews, 37, $762-777$.

Srilatha, K., Devi, B.L.A.P., Lingaiah, N., Prasad, R.B.N., and Prasad, P.S.S. 2012. Biodiesel production from used cooking oil by two-step heterogeneous catalyzed process. Bioresource Technology, 119, 306311. 